Z. Czunyi Anikó

\title{
A változtatási stratégia információjának szükségessége és a kontrolling kapcsolata
}

\begin{abstract}
Anikó Z. Czunyi, Titular University Lecturer: The Relationship between the Strategy of Change and Controlling

Present paper - as a preliminary study to a subsequent one - describes a research programme, which examines the system of connections of change and controlling embracing several companies. The aim of this paper is to shed light on the role of strategic controlling in the implementation of company strategy, avoiding an unsuccessful strategy, defining reversible processes and points of intervention, and also in providing feedback, while devoting a special attention to the formation of strategy-oriented organisations.
\end{abstract}

Már régóta ismert az a tény, hogy a gazdaság rohamosan fejlödik, de ezzel egy időben a menedzsment rendszerek nem képesek ugyanolyan dinamikus változásra. A hagyományos értelemben vett beszámolási rendszerek ma már nem adnak biztonsági alapot egy stratégia meg. valósitásához. A mérlegek, eredmény kimutatások, pénzũgyi szemléletũ és eredménymutatók nem képesek követni a kömyezetben és a szervezeten belül bekövetkezett hirtelen változásokat, a munkaerō szétszórtabb, gyorsabb moz. gását, valamint a kūlönbségeket business és business között. Az úgynevezett ipari korszak után elérkezett a tudás korszaka nem csak a gazdasági fejlódésben, de a stratégia végrehajtásában is. Az anyagi javak (birtok, iparterület, profit, pénzügy) mellett nagyobb súlyt kaptak az intellektuális javak, a humáneröforrás szerepe, a folyamatok és a fejỗdés fontossága is.

Jelen irás egy kutatási program mentén, annak folyamatában készül, amikor a változtatás és a kontrolling kapcsolatrendszerének vizsgálata zajlik tỏbb vállalat esetében.
A stratégiai kontrolling szerepét a stratégia megvalósitásának és a változtatási pontok ösz. szetett kérdésköre kerül vizsgálatra a sikertelen stratégia eikerülése céljából, a visszaforditható folyamatok és beavatkozási pontok meghatározása és a visszacsatolás fontossága szempontjából, kiemelt figyelmet forditva a stratégia kōzpontú szervezetek kialakulására. Több kérdés fogalmazódik meg, melyeket Kaplan és Norton (1996) is feltesznek, vagyis „hogyan is használják a BSC-t a stratégiai központú szervezetek"?

Miután a vállalat menedzsmențe, vezetői, tulajdonosai határozzák meg a stratégiát, a központi szervezeti programcsomagot, maximális mértékben koncentrálnak a stratéglára. A szervezetet, az alkalmazottakat arra vezették rá, hogy alapvetõen más módon cselekedjenek, mégpedig a stratégia szerint. lgy a stratégiai központú szervezetek képesek szakítani a hagyományos felmérési és irányitási rendszerekkel.

A nemzetközi vállalatok esetében jellemzõen kialakultak stratégiai központú szervezetek, amelyek ma még néhány területen a tanulás 
időszakát élik, de a már müködő folyamatok igazolni látszanak a stratégiai eszkōzök hatékonyságát, mely a vállalat eredményességében, a képzett profitban látható és mérhetŏ.

Kaplan és Norton kutatásai során öt fontos alapelv merült fel, amelyek alapjai a sikeres szervezetnek. A stratégiai menedzsment és az ôt kiszolgáló stratégiai controlling ezen alapelvek mentén tevékenykedik.

A mobilizálás változása a vezetơségen keresztül tỏrténik. Ahhoz, hogy a változások bekōvetkezzenek a vezetőségnek ki kell fejlesztenie és meg kell határozni a változás irányát, az elképzeléseket és annak a stratégiáját, azt, hogy hová akarják vezetni a szervezetet? Át kell gondolniuk a számadási kötelezettségüket és meg kell bizonyosodniuk arról, hogy a végrehajtó csapat készen áll a feladatra.

A stratégiát meg kell vizsgálni az ûzemeltetés szempontjából. A BSC és a stratégiai térkép közösen a vállalti stratégiát ragadja meg és olyan szempontból közvetiti, hogy a szervezet azt megérti és a szerint képes cselekedni. Kritikus része ennek a lépésnek az, hogy meg kell határozni a kulcsfontosságú szándékot, mérté. ket, célokat és azon kedvezményeket, melyek a stratégához vezetnek.

A szervezetet be kell áliltani a stratégia sorába. Ha egyszer a BSC-t mint stratégiai eszközt, a legfelsõ szinten megalkotják, akkor ennek el kell jutni az irányitó és háttér egységekbe is. Ez minden egyes területen lehetóvé teszi azt, hogy megértsék és hozzájáruljanak a stratégia megvalósitásához.

Mindenki munkájának legyen stratégiája. Amig a stratégia alulról jövố kezdeményezés hatására formálódhat, az első „vonal" hajija azt végre. Ezért a kommunikáció és mũveltség, a tanultság nagyon fontos a stratégia végrehajtásában. A vezetõ szervezetek személyi BSC létrehozásán dolgoznak, hogy igy tovább vigyék a személyes fejlódés folyamatát a stratégia irányitás szervezetében.

Mindenki munkájának legyen stratégiája. A stratégiát bele kell illeszteni a folyamatba, és a féléves, éves riportálások kapcsán, a vezetőségi értékeléseken szembe kell álitani a célokat, el- képzeléseket a stratégia megvalósitásának fázisaival. A gazdasági, tervező és költségvetési, valamint a legjobb gyakorlati és intellektuális rendszerek kapcsolódjanak a BSC-vel, a stratégia folyamataival. (Kaplan és Norton, 1996)

Jelen tanulmány készitése során bemutatásra kerūl a stratégiai menedzsment és a vállalati controlling kapcsolatrendszere, és a stratégia megvalósitásához szükséges eszközök, mely kutatások során eltérõ gondolatokat és hasonló folyamatokat, illetve párhuzamosságokat tapasztalhatóak. A vizsgálat során hazai és nemzetkōzi nagyvállalatok kontrolling szervezetei és stratégia megvalósitó módszerei kerülnek összehasonlításra.

A stratégiai alapelvek érvényesülése a dinamikusan nővekvő, perspektivikus vállalatok stratégiai szervezetében kerü'nek elōtérbe, ahol a stratégiai alapelvek érvényesülése pontról pontra érezteti hatását. Ezen vállalatok esetében a mobilizálás, a pontos célmeghatározás, a változások ideje és iránya, a stratégiai szempontú üzemeltetés kiforrolt, a stratégia beépül a szervezetbe.

A munkavállalók a stratégiát saját „érdekrendszerükön" keresztül fogadták be. A beszámoltatások, a meghatározott idõszakonként történő eredményértékelések aktívan bevonják a dolgozókat a stratégia megvalósitásába. A nemzetkōzi vállalatok alapvető motivációs eszközként használják munkavállalók érdekeltté tételét a kitüzött célok megvalósitásban. A feladatok nem teljesitése, az elmaradások adott esetben szankciókat (juttatás megvonások) vonnak maguk után, ahol a „büntetések" végrehajtása is következetesen történik. Az egyéneket csak személyes motiváltságukon keresztül lehet és tudja a menedzsment irányitani, mely az utóbbi két vállalatnál is tapasztalható volt.

Természetesen, a stratégia megvalósításában is vannak különbségek. A stabil szervezetben kiegyensúlyozott, tōbbségében elégedett munkavállalókkal, kiszámítható, tervezhető mũködésben és szervezett struktúrában mūkōdnek. llyen esetben nagy hangsúly kerül a teljesitményértékelésre, a visszacsatolásra, mellyel 
Z. Czunvi Anikó: A változtatási stratégia informáciöjának szükségessége...

megnyilik az idöben történō beavatkozás és a változtatás lehetősége. A vállalatok szervezeti egységeinek kapcsolata szoros, a menedzsment a tulajdonosok által szigorúan ellenôrzōtt, az egységek controlling szervezete függelmileg és szervezetileg a központi controlling szervezetéhez tartozik.

Fentiekkel ellentétben sérülni látszik sok hazai vállalat mūkődése esetében a stratégia beillesztése a szervezetbe". A stratégiai eszközök használata, az információk folyamat szerinti áramlásának biztosítása elvárás a menedzsmenttel szemben, de az információk elakadásával nem biztositott, sôt több ponton sérūl annak megfelelö mũködése. Ezeken a szervezeteken belūi gyengülni látszik a stratégiai controlling szerepe. A vállalton belūl a szervezeti átalakulás eredményeként „kiskirályságok” vannak kialakulóban, ahol az egyéni érdekek kerülnek felszinre a vállalati érdek leple alatt. A stratégiai eszközōk használata sok esetben a tulaj- donosok elvárása, akik érthető módon mükōdõ, más társaságoknál eredményt felmutató modell használatát kivánják bevezetni és alkalmazni. Tōbb „látszatintézkedés" tapasztalható, az egyes vállalatoknál, amellyel a ,helyi" menedzsment a tulajdonosok elvárásainak kiván megfelelni (adott esetben „szebb kép” bemutatásával), azonban (például az eredményérdekeltség terūletén) az őnalló társaságok vezetői „ellenérdekữ felekké válnak.

Kiemelten kezelendő a nagyvállalatok esetében az önálló egységek vezetōinek „teljesitményértékelésỉ rendszere, melyben lényegesen nagyobb hangsúlyt kell fektetni az összvállalati stratégiai célok megvalósitásának ösztönzésére, a controlling szervezetek megfelelö szintre tổrténő struktúrálására és annak szervezeten belüli súlyozására.

Mit kell, és mit tud tenni a menedzsment, és hogyan tudja megvalósitani a stratégiát válságos kōrülmények kōzött? Képes-e a menedzsment a

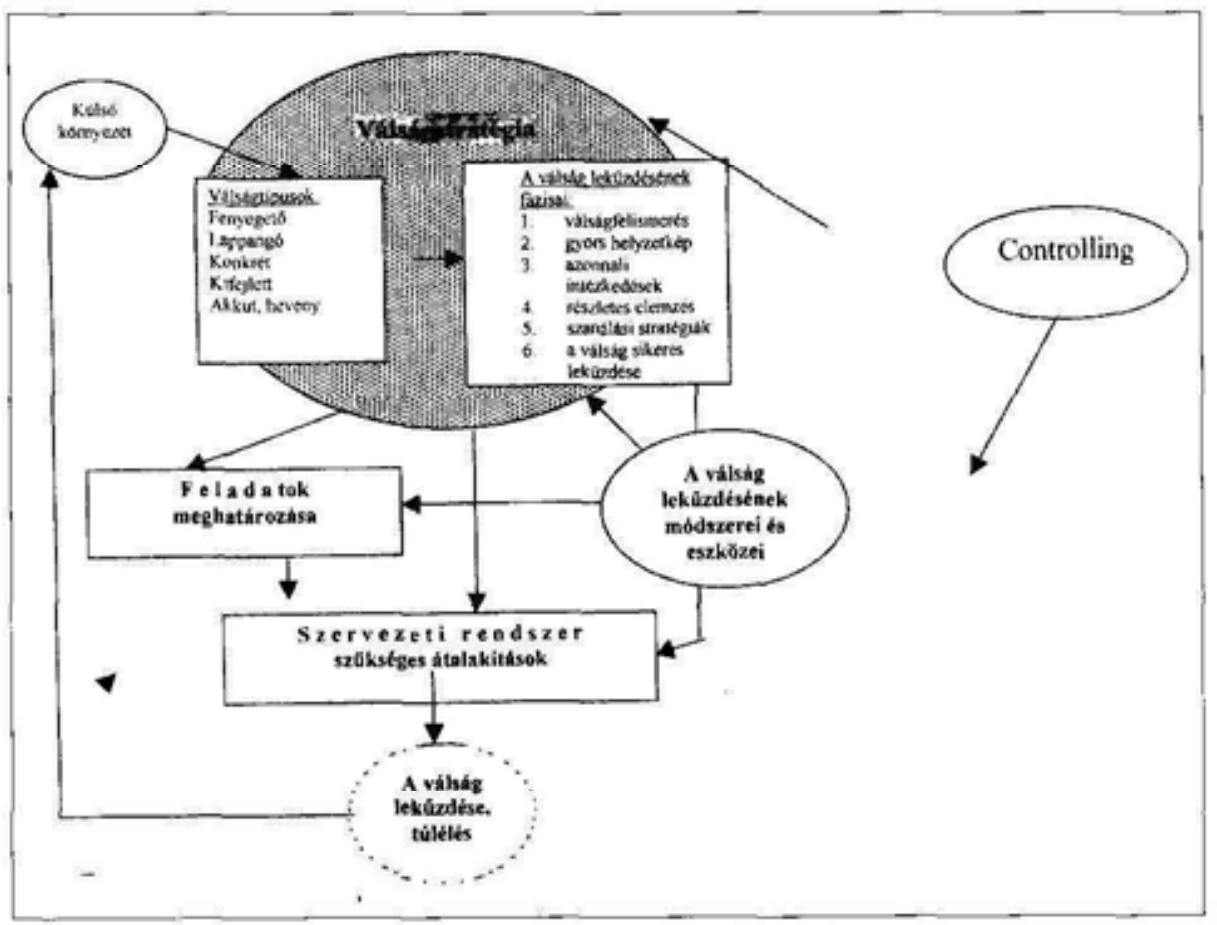

1. ábra: A válságstratégia összefüggései Forrás: a szerzó saját összeáilítása 
szervezetet tudományos elvek mentén irányitani és tud-e ezekkel eredményeket elérni?

A válságos körülmények közōtt nagyobb odafigyelést, fegyelmezettséget, összefogást és kitartást igényel az úgynevezett válságstratégia megvalósitása, mint kiegyensúlyozott, kiszámitható és tervezhető vállalati környezetben. Ebben a kritikus helyzetben a controlling szerepe megváltozik. Nem a klasszikus értelemben vett teljes szervezetet átfogó tevékenységére kell koncentrálnia, hanem a válságmenedzsment kiszolgálása a fó feladata. Nem kell, hogy minden ponton elemzéseket végezzen, hiszen az idővel való versenyfutás nem teszi ezt lehetơvé számára. Kulcs fontosságú kérdésekben kell támogatnia a menedzsmentet, a szervezet reakcióidején belül annak érdekében, hogy a kritikus pontokon a beavatkozás eredményes és hatásos legyen. A döntés elökészitésével már a lehetséges kimeneteket, hatásokat is mérlegelnie kell, annak kockázati elemei ismeretében. (1. ábra)

A változtatások, esetleg válságok idején: a szervezet mobilizálása, és az üzzemeltetés nehezen tervezhetō, a menedzsmentnek sok esetben azonnali intézkedéseket kell végrehajtatnia, a szervezetet átszövi a ,túlélés" szelleme. Valamennyi munkavállalónak a stratégia végrehaj- tása a célja, hiszen a munkahelye, adott esetben a megélhetése függ a teljesitményén. A munkahely megtartása, a félelem annak elvesztésétöl mintegy kényszerũ erơvel hat a munkavállalókra. Mindezek alapján a stratégiát, mindenki stratégiájának nevezhetjük, amely átjárja a szervezetet, és annak elválaszthatatlan részévé vált.

Nevezhetjüke a „túlélési célt" stratégiának? Ebben az esetben is a menedzsment a vállaltot a kitüzött cél felé kivánja vezetni, bár a cél elérésének időtávja nem, vagy nem minden esetbe ismert. A stratégia megvalósitásához a menedzsment felhasználja a szervezetben és a környezetben lévõ lehetóségeket, a dolgozók motiválásával, számadásával törekszik végrehajtani a kitūzött feladatokat. A vizsgálat természetesen ezen a ponton nem fejezódhet be, hiszen fontos a tudományos stratégiai szempontok használatának érvényesülése, és a stratégiai eszközök használata válságos körülmények kōzött is.

Ez a vázlatos ismertetés csak érzékeltetni kivánta a téma időszerũségét, illetve azokat tartaimi jellegzetességeket, amelyek, reméljük, a vizsgálat alapján új eredményeket fognak hozni, és amelyekről az ECONOMICA hasábjain szeretnék majd beszámolni. 